\title{
INTER-RELATIONSHIP BETWEEN FIRM GROWTH AND PROFITABILITY IN A CONTEXT OF ECONOMIC CRISIS
}

\author{
Yolanda FUERTES-CALLÉN ${ }^{*}$ (iD) Beatriz CUELLAR-FERNÁNDEZ $^{(D)}$ \\ Department of Accounting and Finance, University of Zaragoza, Zaragoza, Spain
}

Received 8 May 2018; accepted 14 November 2018

\begin{abstract}
This paper examines the dynamics between growth and profitability in an economic crisis context by considering the endogeneity of this relationship. It also analyzes the role of innovation and export intensity in the growth-profit relationship. Using a large firm-level dataset comprising Spanish manufacturing companies during the pre-crisis (2000-2007) and the crisis (2008-2014) period, static and dynamic panel data models are estimated.

The analysis suggests the following results. First, in the short term, growth has a positive impact on profits, while the effect of profits on growth depends on the measure of growth used. So, employee's growth requires previous profit but profit does not play a major role as determinant of sales growth. Second, profit rates are found to persist in the short term. In contrast, a reversion of turnover and employees growth rates is observed. Thirdly, the moderation analysis applied shows that the strategy that has enabled firms to grow is export. Moreover, the influence of the export intensity on profitability in the economic crisis period is obtained indirectly through sales and employee's growth. Unlike expected, innovation efforts do not moderate the relationship between profitability and firm growth.
\end{abstract}

Keywords: firm's growth, profitability, innovation, export, manufacturing industry, economic crisis.

JEL Classification: M21, M4, O3.

\section{Introduction}

Business growth and profitability, as well as the link between both, have attracted, and continue to attract, the interest of researchers for decades. It is not surprising given that the binomial growth-profitability is the essence of business practice. The use of growth as a measurement of firm performance has traditionally been based on the belief that growth is a precursor of sustainable competitive advantages and profitability (Fitzsimmons, Steffens, \& Douglas, 2005). Growth that is not accompanied by profitability does not seem sustainable in the long term. Firms that grow at the expense of their profits are forced to seek external financing, which could result in financially difficult situations.

\footnotetext{
${ }^{\star}$ Corresponding author. E-mail: yfuertes@unizar.es
} 
Despite the numerous studies carried out and the increasing interest in the literature, the relationship between growth and profitability is not yet well known and neither are the persistence and pre-requisites for achieving growth and profitability. The nature of this relationship is difficult to capture. The endogeneity between growth and profitability complicates understanding of this relationship's causality and direction.

In favorable economic situations its analysis is of great concern, but it is essential in times of economic crisis since, as some recent studies seem to indicate (Federico \& Capelleras, 2015; Yoo \& Kim, 2015), the relationship between profitability and growth can vary according to the economic environment the company faces, and the effects of growth determinants tend to change.

Recent studies have shown that the 2008 global financial crisis has modified the growth and performance of companies, particularly the small and young ones (Moscarini \& PostelVinay, 2012; Ferrando, Marchica, \& Mura, 2017). The effect of profit on growth is likely to be positive in an environment that encourages investment and growth. Then, if the business climate is not favorable to investment, the link of profit to growth gets weak (Lee, 2014). The recession involved significant impacts, particularly a major shrinking of industrial production worldwide and an unprecedented worldwide drop in commerce in the post-war era. In Spain, the recession managed to wreak destruction on the business fabric. The firms that survived the crisis showed growth rates far below those they enjoyed in the previous period of expansion and many others suffered a decline.

The main objective of this paper is to know how firms' growth and profitability adapt to adverse market conditions. Two research questions are tackled. The first is to know if the dynamics between firm growth and profitability are influenced by the economic environment, and so the persistence of both growth and profits. To that end, we have analyzed the bidirectional causal relationship between growth and profitability in a sample of Spanish manufacturing companies during the period 2000-2014 which gives us an unbalanced panel composed by 26,205 firm-year observations. This period covers the last global economic downturn so we can learn the effect of an unstable economic period on the growth-profit relationship. We use both static and dynamic panel estimators. Data comes from the Business Strategy Survey (hereinafter referred to by its Spanish abbreviation, ESEE), conducted in Spain by the SEPI Foundation (a state-owned holding company) and published by the Ministry for Science and Technology.

The second research question evaluates the effect of internationalization and innovation strategies in the growth-profit relationship. These two strategies are considered to play a key role in crisis periods to grow and to achieve superior performance. We have conducted a moderation analysis to assess the role of firm innovativeness and export intensity in the firm growthperformance relationship. Our findings contribute to the literature first by providing new evidence on the relationship between firm growth and profitability in a context of economic crisis, and findings on the growth rates autocorrelation and profit persistence in this context.

The rest of this paper is organized as follows. The theoretical background of firms' growth and its influencing factors are provided in section 1. Sample, data and empirical analysis are presented in section 2. Section 3 provides results. Finally, we discuss our main findings and provide conclusions. 


\section{Theoretical background and related literature}

\subsection{The growth-profit relationship}

The literature on firm growth focus mainly on empirical investigations along the framework of Gibrat's Law (Gibrat, 1931). According to it business growth follows a random walk. Since its publication to date, numerous studies have tried to assess the Law of Proportionate Effects (LPE) and have led heterogeneous results remaining as one of the most conflicting and continuously explored issues in the industrial economics literature.

On segmenting the analysis by considering firm age, the studies by Giotopoulos and Fotopoulos (2010), Coad, Daunfeldt, and Halvarsson (2018) evidence positive autocorrelation in young firms, while the growth pattern of old firms follows a random-walk stochastic process that does not tend to persist in the following periods. Coad (2007), Reichstein, Dahl, Ebesberger, and Jensen (2010), Daunfeldt and Halvarsson (2015), show that small fast-growing firms present a negative autocorrelation in annual growth. Canarella and Miller (2018) find a non-linear and concave-in-size relationship between growth and size.

Research into the persistence of profit (POP) affirms that profitability converges at a particular level for all firms and no company can maintain profitability above the average in the long run. However, numerous empirical papers indicate profit persistence for different industries and different time periods (Mueller, 1990; Cable \& Mueller, 2008; Goddard, Liu, Molyneux, \& Wilson, 2013; Pattitoni, Petracci, \& Spisni, 2014; Tsoulfidis, Alexiou, \& Parhenidis, 2015) and thus contradict the neoclassical model of perfect competition. Recently, Amidu, and Harvey (2016), Gugler and Peev (2018) evidence that 2008 financial crisis reduced the level and the speed of profit persistence. Hirsch (2018), in his meta-regression analysis on profit persistence studies, find that the analyzed countries and periods of time are significant drivers of heterogeneity in reported persistence estimates.

The relationship between both, growth and profit, is at the heart of major theories such as the theory of economic development (Schumpeter, 1934), the theory of entrepreneurship (Kirzner, 1979) and the theory of firm growth (Penrose, 1959). Many economists currently accept that maximizing profit and business growth are two rival objectives within a firm (Jang \& Park, 2011). Consequently, various hypotheses are established on the relationship between both.

Several theories defend the positive relationship between growth and profitability. Business growth is considered to lead to a decrease in costs through economies of scale (Gupta, 1981), network externalities, outsourcing and an increase in negotiation power with providers and clients (Markman \& Gartner, 2002), learning curves (Coad, 2007), and so on, which allow firms to increase their profitability. Lee (2014), Yoo and Kim (2015), Federico and Capelleras (2015) present evidence of the positive influence of growth on profits.

From the point of view of traditional micro-economic theories, firms perform the most profitable projects before continuing their expansion with projects that are less profitable. As a company increases in size, it becomes more difficult for its managers to increase its profitability (Davidsson, Steffens, \& Fitzsimmons, 2009). A firm's increase in size also involves more organizational and management complexity, which diverts managers' attention from controlling operational costs, thus leading to a decrease in the profit rate. Thus, growth is 
not sufficient to ensure profits. Empirical studies such as Goddard, Molyneux, and Wilson (2004), Jang and Park (2011) conclude that these variables are unrelated or even show that current and prior growth rates have a negative effect on current profit rates.

Evolutionary theories on business growth, led by the study by Alchian (1950), argue that profitability involves the expansion of the company. They maintain that fitter firms survive and grow while less viable firms decline until they close for good. Along the same lines, although with different arguments, the resource-based view (RBV) theory maintains that firms showing above-average profitability rates are more likely to grow. Empirically, the studies of Coad (2007), Davidsson, Steffens, and Fitzsimmons (2009), Kachlami and Yazdanfar (2016) evidence a positive effect of profitability on growth, and Cowling (2004) finds that growth and profit facilitate each other.

Other theories, however, posit that the association between both variables is not so clear. Recent empirical evidence even reveals a possible negative effect of profit on growth (Lee, 2014). Federico and Capelleras (2015) do not observe a significant influence of profitability on growth in a sample of young manufacturing firms and Coad, Frankish, Roberts, and Storey (2013) report a negative effect between both, concluding that young companies may decide to grow at the expense of profits since growth and survival are closely related. Lee (2018), in a sample of Korean firms over the period 1990-2012, evidences that the effect of profits on growth is negative after the financial crisis.

As discussed above, empirical studies provide mixed and inconclusive evidence. The ambiguity in the results might stem from the sector or country used in the analysis, the use of different estimation methods and the period analyzed.

\subsection{The influence of innovation and export on firm growth and profitability}

During a period of economic crisis, companies must adjust their strategies to the environmental challenges in order to gain competitive advantage and survival. Recent literature addresses the key role strategies such as innovation or internationalization play in a firm managing to achieve superior performance.

The predominant means for many firms to internationalize and access foreign markets is exporting (Lee, Beamish, Lee, \& Park, 2009). The empirical evidence highlights the positive influence of exports on firm growth, not only due to their direct effect on sales, but also their indirect effects arising from income diversification, the firm's development of new capabilities (Shaver, 2011), the possibility of performing economies of scale in firms whose local market is small (Caves, 1996) and the increase in their scope and experience (Riahi-Belkaoui, 1998). However, implementing an export strategy involves significant costs and introducing substantial changes in the firm that are often associated with the liabilities of foreignness and newness (Zaheer, 1995).

Several studies have examined the internationalization-performance relationship by focusing on firms' endogenous factors, such as size and firm-specific assets, and exogenous factors, for example culture, business environment and institutions (Hsu, Chen, H. L., \& Cheng, C. Y., 2013). The results have been inconsistent. Some authors evidence a positive effect of internationalization on firm performance (Pangarkar, 2008), while other authors 
show a negative relationship (Geringer, Tallman, \& Olsen, 2000), an S-shaped, a U-shaped or even an inverted U-shaped effect (Chao \& Kumar, 2010). The reasons provided for justifying the range of results include the variety of variables used in the studies to measure performance and even whether the firm has engaged in internationalization and the extent of that engagement.

Together with exports, innovation is another key strategy. A firm's main motivations to innovate include its aim to increase its business performance and competitive edge. Although theoretical and descriptive studies seem to agree on innovation's influence on a firm's performance and survival (Cho \& Pucik, 2005), empirical evidence provides disparate results that are modest and disappointing. Studies by Coad and Rao (2008), Geroski and Machin (2013) and Rousseau, Blake, Madden, and Crook (2016) evidence a positive association between growth and business performance while other studies do not find a relationship between them or even show a negative impact (Bottazzi, Dosi, Lippi, Pammolli, \& Riccaboni, 2001; Lööf \& Heshmati, 2006). As Demirel and Mazzucato (2012) evidence, the impact of innovation on firm growth is far from being a simple relationship; it is highly conditional upon a combination of firm-specific characteristics.

Although most studies have analyzed both strategies in an isolated way, there are compelling reasons to expect a positive interdependence between exports and innovation. Thus, Rodil, Vence, and Sanchez (2016) evidence that exporting activity increases when firms are innovative, and that complementarities among innovation activities (variety) help firms to export more. Boermans and Roelfsema (2016) show a positive impact of internationalization on innovation. Internationalization increases firm performance directly and indirectly through innovation.

Filatotchev and Piesse (2009), Golovko and Valentini (2011), Alarcón and Sánchez (2016) conclude that innovation and exports are complementary growth strategies and that the positive effect of innovative activity on a firm's growth rate is higher for firms that also engage in exports, and vice versa. Guarascio and Pianta (2017) suggest the existence of a "virtuous circle" in which the success in new products will lead to faster export growth and this in turn may lead to a higher growth of profits that - with a lag - can finance innovative activities and support continuing product innovation.

In addition, most of the academic literature analyzing the role of firm's strategic orientations in improving business performance has been conducted in stable economic environments (Hakala, 2011). However, the effect in period of economic crisis is still unclear. The combination of firm strategies such as exports and innovation could help firms in managing unfavourable economic conditions (Burger, Damijan, Kostevc, \& Rojec, 2017). Export and innovationoriented companies are expected to exhibit better resistance to economic recession.

\section{Data, variables and empirical model}

\subsection{Data and sample}

This study analyzes a sample of Spanish manufacturing companies from 2000 to 2014. Data comes from ESEE, conducted in Spain by the SEPI Foundation. One of the most relevant characteristics of the ESEE is its representativeness. The sample is representative of the 
population of firms with ten or more employees involved in manufacturing industries with at least one production facility in Spain (micro-firms are, therefore, not sampled). The survey includes information on around 2000 companies every year.

Manufacturing was the second largest of the NACE sections within the EU-28's nonfinancial business economy in terms of its contribution to employment $(22.3 \%)$ and the largest contributor to value added of the non-financial business economy, accounting for more than one quarter of the total (26.1\%). Although the importance of industry in gross domestic product (GDP) has fallen in Spain and in many other surrounding countries, as highlighted by the European Commission (EC) (2014), the economic importance of industrial activities extends beyond their contribution to GDP, especially in exports, in private R\&D efforts and their capacity to create employment. Consequently, the EC emphasizes the need for a strong industrial base to play a key role in the economic recovery and competitiveness of Europe.

\subsection{Variables and statistics}

A variety of indicators are applied in the literature to measure business growth, mainly growth in assets, sales and employees. Although these indicators are often used as alternative proxies to measure business growth, each of them provides information on different growth aspects. Therefore, these measurements are not interchangeable. Consequently, the development of growth in sales and employees was analyzed jointly in our study to improve understanding of the business growth process. The profitability indicator used was return on assets (ROA), measured as earnings before interest and taxes divided by total assets. The influence on growth of the two analyzed strategies, innovation and exports, is measured by using the ratio of a firm's export sales over its total sales as an indicator of a firm's export intensity. Similarly, we measured a firm's innovation effort as its R\&D expenses over its total sales.

In addition to the major variables, the following control variables were introduced: size (the natural logarithm of total assets), liquidity (current assets/current liabilities) and debt (total liabilities as a percent of total assets).

After deleting observations with atypical data or missing values, the final sample refers to an unbalanced panel composed by 26,205 firm-year observations. To mitigate the influence of outliers the observations falling in the top or bottom $1 \%$ of variables in each year were excluded. Table 1 reports the description and summary statistics for the variables used and the correlation among these variables is shown in Table 2.

Table 1. Summary statistics (sample period 2000 to 2014)

\begin{tabular}{|c|c|c|c|c|c|}
\hline Variable & Description & Mean & $\begin{array}{l}\text { Standard } \\
\text { Deviation }\end{array}$ & Minimum & Maximum \\
\hline SG & $\begin{array}{l}\left(\text { Total Sales }_{t}-\text { Total sales }_{t-1}\right) / \text { Total } \\
\text { Sales }_{t-1}\end{array}$ & $1.37 \%$ & 0.211 & $-75.9 \%$ & 128.4 \\
\hline EG & $\begin{array}{l}\text { (Total employees } t-\text { Total em- } \\
\text { ployees }_{t-1} \text { ) / Total employees } \\
t-1\end{array}$ & $-1.69 \%$ & 0.155 & -68.5 & 110.1 \\
\hline $\mathrm{ROA}$ & Return on Assets & $10.87 \%$ & 0.109 & $-43.65 \%$ & $89.7 \%$ \\
\hline Size & Total Assets (th. euros) & $69,007.49$ & $432,599.3$ & 4.808 & $26,000,000$ \\
\hline
\end{tabular}


End of Table 1

\begin{tabular}{|c|l|c|c|c|c|}
\hline Variable & \multicolumn{1}{|c|}{ Description } & Mean & $\begin{array}{c}\text { Standard } \\
\text { Deviation }\end{array}$ & Minimum & Maximum \\
\hline Liquidity & Current Assets / Current liabilities & 1.97 & 1.66 & 0.088 & 21.6 \\
\hline Debt & Total Liabilities / Total Assets & 0.558 & 0.227 & 0.041 & 0.99 \\
\hline $\begin{array}{c}\text { Innovation } \\
\text { (Innov) }\end{array}$ & R\&D expenses / Total Sales & $0.69 \%$ & 0.016 & 0 & $14.1 \%$ \\
\hline Export & Export Sales/Total sales & $28.9 \%$ & 0.276 & 0 & $99.1 \%$ \\
\hline
\end{tabular}

Table 2. Results of the correlation analysis

\begin{tabular}{|c|c|c|c|c|c|c|c|}
\hline & $S G_{t}$ & $E G_{t}$ & $R O A_{t}$ & $\operatorname{Size}_{t-1}$ & Liquidity $_{t-1}$ & $\operatorname{Debt}_{t-1}$ & Innov $_{t-1}$ \\
\hline$S G_{t}$ & 1 & & & & & & \\
\hline$S G_{t-1}$ & $0.165^{*}$ & & $-0.045^{\star}$ & & & & \\
\hline$E G_{t}$ & $0.388^{*}$ & 1 & & & & & \\
\hline$E G_{t-1}$ & $0.084^{*}$ & $0.092^{*}$ & 0.015 & & & & \\
\hline$R O A_{t}$ & $-0.024^{*}$ & $0.016^{*}$ & 1 & & & & \\
\hline$R O A_{t-1}$ & $0.039^{*}$ & 0.014 & $0.188^{\star}$ & & & & \\
\hline Size $_{t-1}$ & $0.049^{*}$ & $0.034^{\star}$ & -0.011 & 1 & & & \\
\hline Liquidity $_{t-1}$ & $-0.023^{\star}$ & -0.006 & $-0.059^{\star}$ & $-0.018^{\star}$ & 1 & & \\
\hline $\mathrm{Debt}_{t-1}$ & $0.019^{*}$ & 0.008 & $0.025^{*}$ & $-0.096^{*}$ & $-0.566^{\star}$ & 1 & \\
\hline Innov $_{t-1}$ & $0.043^{*}$ & $0.041^{*}$ & -0.005 & $0.278^{*}$ & -0.002 & $-0.03^{*}$ & \\
\hline Export $_{t}$ & $0.029^{*}$ & 0.006 & -0.018 & $0.246^{*}$ & 0.002 & -0.018 & $0.192^{*}$ \\
\hline
\end{tabular}

${ }^{*}$ p-value $<0.05$.

Table 3 shows the development over time of the three variables used in the study to measure growth and profitability. The impact of the recession starting in the 2008 financial year can be seen in all of them. Consequently, the increase in sales was negative in the 2007-2009 period, and, despite the recovery in the most recent years analyzed, the average growth rate did not return to its average pre-recession rate. The development in the number of employees follows the same trend, showing that employment was destroyed from the 2007-2008 period to 2012-2013. The average profitability gradually fell throughout the period, dropping from an average rate of $12.17 \%$ in the $2006-2007$ period to a rate of $6.6 \%$ in the $2012-2013$ period. As in growth variables, a slight improvement was noticed in the last year analyzed.

Table 3. Evolution of sales and employee growth and ROA from 2000 to 2014 (mean values)

\begin{tabular}{|l|c|c|c|c|c|c|c|}
\hline \multicolumn{1}{|c|}{ Years } & $00-01$ & $01-02$ & $02-03$ & $03-04$ & $04-05$ & $05-06$ & $06-07$ \\
\hline$S G$ & 0.07 & 0.01 & 0.03 & 0.05 & 0.03 & 0.07 & 0.07 \\
\hline$E G$ & 0.02 & -0.002 & 0.02 & 0.00 & -0.01 & 0.00 & 0.00 \\
\hline$R O A(\%)$ & $14.37 \%$ & $13.09 \%$ & $13.01 \%$ & $11.57 \%$ & $11.68 \%$ & $11.65 \%$ & $12.17 \%$ \\
\hline
\end{tabular}


End of Table 3

\begin{tabular}{|l|c|c|c|c|c|c|c|}
\hline \multicolumn{1}{|c|}{ Years } & $07-08$ & $08-09$ & $09-10$ & $10-11$ & $11-12$ & $12-13$ & $13-14$ \\
\hline$S G$ & -0.04 & -0.20 & 0.03 & 0.02 & -0.05 & 0.00 & 0.04 \\
\hline$E G$ & -0.06 & -0.09 & -0.03 & -0.03 & -0.05 & -0.02 & 0.01 \\
\hline$R O A(\%)$ & $8.8 \%$ & $6.8 \%$ & $6.6 \%$ & $6.0 \%$ & $6.1 \%$ & $6.6 \%$ & $7.6 \%$ \\
\hline
\end{tabular}

\subsection{Empirical model}

The relationship between firm growth and profitability was tested using regression models in which the bidirectional causal relationship was addressed. The first model considers profitability as a determining variable of growth, while in the second, growth is the factor explaining profitability. The influence of the strategies firms choose as a means to obtain growth and profitability was contrasted in the second phase.

In equation (1) business growth is explained by profitability together with the previously defined control variables and two lags of the dependent variable. Following Bottazzi, Coad, Jacoby, and Secchi (2011), Federico and Capelleras (2015) two lags of the dependent variables are introduced in each equation to account for possible omitted variables, to attenuate any autocorrelation in the residuals and to improve the efficiency of the estimators in the presence of endogenous variables:

$$
G R_{i, t}=\alpha_{1 i}+d t+\sum_{k=1}^{2} \beta_{k} G R_{i, t-k}+\delta R O A_{i, t-1}+\sum_{k=1}^{3} \gamma_{k} X_{t-1}+e_{i t},
$$

where $G R$ is firm growth, measured by the increase in sales $(S G)$ or by the increase in employees $(E G)$ and $R O A$ is profitability measured at the start of the growth period $(t-1) . X$ is the matrix of the control variables: size, liquidity and debt. $\alpha_{i}$ measures non-observable heterogeneity between individuals and is constant over time, while $d t$ is a dummy variable that measures effects over time that are constant between individuals.

Equation (2) proposes growth in the previous $(t-1)$ and in the current $(t)$ years as factors to explain profitability, considering that growth can generate profitability from the moment it occurs, in other words it is a profitable growth. Control variables and two profitability lags are also included:

$$
R O A_{i, t}=\alpha_{2 i}+d t+\sum_{k=1}^{2} \beta_{k} R O A_{i, t-k}+\sum_{k=0}^{1} \delta_{k} G R_{i, t-k}+\sum_{k=1}^{3} \gamma_{k} X_{t-1}+e_{i t} .
$$

To analyze the effect of economic crisis in the relationship between growth and profitability, we include in each equation a dummy variable (crisis) that multiplies $R O A$ and $G R$ variables. Crisis takes value 1 in the years of crisis (2008-2014) and zero otherwise. If the relationships are different in crisis period, we expect coefficients on the interaction term statistically significant.

Finally, equations (3) and (4) include variables measuring business strategies, export intensity and innovation effort as explanatory variables, besides those defined in equations (1) and (2): 


$$
\begin{gathered}
G R_{i, t}=\alpha_{3 i}+d t+\sum_{k=1}^{2} \beta_{k} G R_{i, t-k}+\delta R O A_{i, t-1}+\sum_{k=1}^{3} \gamma_{k} X_{t-1}+\lambda \text { Innov }_{i, t-1}+\phi \text { Export }_{t}+ \\
\varphi R O A_{i, t-1} \text { xInnov }_{i, t-1}+\psi R O A_{i, t-1} \text { Export }_{t}+e_{i t} ; \\
R O A_{i, t}=\alpha_{4 i}++\sum_{k=1}^{2} \beta_{k} R O A_{i, t-k}+\sum_{k=0}^{1} \delta_{k} G R_{i, t-k}+\sum_{k=1}^{3} \gamma_{k} X_{t-1}+\lambda \text { Innov }_{i, t-1}+\phi \text { Export }_{t}+ \\
\varphi G R_{i, t} \text { xInnov }_{i, t-1}+\psi G R_{i, t} \text { Export }_{t}+e_{i t} .
\end{gathered}
$$

Innov $v_{i t-1}$ is the variable measuring firm's innovation efforts and Export ${ }_{i t}$ is the variable that measures export intensity in the same measurement period as growth and profitability. We propose them as moderator variables in the relation between profit and growth. In each equation the moderator variable effect is represented by the interaction effect between the GR (ROA) variable and the Export and Innov variables.

Since our data set is a pooled time-series cross-sectional database, regression models were estimated using various regression estimations: pooled OLS, GLS-Panel regression and system GMM estimator. The generalized least squares (GLS) procedure is more appropriate than pooled OLS estimator when there exists of cross-sectional heteroskedasticity and serial correlation in the idiosyncratic errors, as is our case.

By definition, the four above-described equations are dynamic panel data models since they include lags of the dependent variable. There are endogenous problems in the dynamic models as the random perturbations are correlated with lagged variables. Furthermore, although the literature establishes a causal relationship between growth and profitability, the direction of this relationship is not clear since evidence of causality was found in both directions, which also causes endogenous problems in the models.

In presence of endogeneity, OLS, or fixed-effect or random-effect estimates are biased and inconsistent because endogeneity affects the orthogonality of the variables to the residual errors. Moreover, the lagged values of the dependent variable are correlated with the individual specific fixed effects included in the error term, originating the "Nickell bias" (Nickell, 1981).

To solve it, we use the system GMM estimator for dynamic panel data models developed by Arellano and Bover (1995), Blundell and Bond (1998), which produces unbiased and consistent estimates after controlling for endogeneity. We estimated the system GMM using a two-step estimator because it is robust enough to detect heteroscedasticity.

System GMM uses levels and differences equations to instrument endogenous regressors, so they are also able to deal with time invariant firm-specific attributes. This estimation is also especially suitable for cases such as ours in which: the number of individuals is far higher than the number of years; the relationship is linear; the model is dynamic; the independent variables are not strictly exogenous, meaning correlated with past and possibly current realizations of the error; there are individual effects and heteroskedasticity and autocorrelation within individuals but not across them (Roodman, 2006). In summary, system GMM estimators are adequate in our research due to their ability to deal with both endogeneity and heterogeneity. 
To derive the instrument set for the GMM estimation of equations sequential exogeneity is required. This assumption allows growth and profitability to be determined by past and present realizations of the other variable, but not future values. Sequential exogeneity is a weaker condition than strict exogeneity, and provides a more accurate setting for the analysis of the growth-profitability relation. Additionally, it is assumed that there is some form of persistence in growth and profits, such that past values of themselves may serve as valid instrumental variables.

In this paper lagged of dependent variables (levels and differences) were used. The lags of the variable causing the endogeneity due to bidirectional causality were also used as instruments. In system GMM, the validity of the additional instruments requires orthogonality between the differences of the errors and the lagged levels of the variables used as instruments and, also, orthogonality between the firm specific effects and the lagged differences of the variables used as instruments. Consequently, is necessary to check the validity of the instruments using a specification tests. We report the over-identification Hansen J test in each table. According to the estimation results, the test statistics indicate that our instruments are in fact valid and that the moment conditions are met. Another requirement is to have no serial correlation of the second-order error terms. The test for second-order autocorrelation of the residuals $(A R(2))$, developed by Arellano and Bond (1991), was reported to evaluate the specification of the model.

\section{Results}

\subsection{The dynamics between growth and profits}

Table 4 presents the results of the regression analysis in which ROA explains sales and employee growth. Starting with the analysis of the persistence of growth rates, the estimated coefficient for the first lag of sales and employee growth is negative and statistically significant $(-0.05$ and -0.034 respectively in the system GMM estimation). These values imply that sales (employees) growth of $1 \%$ in previous year will translate to a decrease of $0.05 \%(0.03 \%)$ in the current period. The coefficient of the second lag is also negative and significant in the case of sales growth, which is consistent in the three estimation methods. The negative sign in the estimated coefficients indicates a reversion in growth rates in two consecutive years.

The coefficients on the interaction terms SG $x$ crisis and EG $x$ crisis are not statistically significant, which indicates that the reversion in growth rates does not change in the crisis period. These results are consistent with the idea that extreme growth rates are not sustainable. Higher growth today leads to lower growth in the following period, which suggests mean reversion in a firm's growth process.

Concerning the relationship between profitability and sales growth, the estimated coefficient for the profitability variable is negative and statistically significant in OLS and GLS estimation. After controlling for endogeneity, the system GMM estimation indicates that previous profits have a slight but positive statistically significant influence on subsequent sales growth. However, the multiplicative term between $R O A$ and crisis dummy variable is negative and statistically significant, telling us that the association between profitability and 
sales growth in the years of crisis is weaker. To check its relevance, we have tested if 0.125 (ROA coefficient) -0.144 (ROA $x$ crisis coefficient) $=0$ but the null hypothesis cannot be rejected. Therefore, there is no relevant association between previous profits and current growth in the crisis period.

Table 4. Results of the panel estimation: growth model

\begin{tabular}{|c|c|c|c|c|c|c|}
\hline \multirow{2}{*}{$\begin{array}{l}\text { Dependent } \\
\text { variable: }\end{array}$} & \multicolumn{3}{|c|}{$S G(E Q 1)$} & \multicolumn{3}{|c|}{$E G(E Q 1)$} \\
\hline & OLS & GLS & GMM & OLS & GLS & GMM \\
\hline$S G_{t-1}$ & $0.060^{\star \star *}$ & $-0.066^{* * *}$ & $-0.050^{* * *}$ & & & \\
\hline$S G_{t-2}$ & $-0.029^{* *}$ & $-0.029^{\star}$ & $-0.091^{*}$ & & & \\
\hline$S G_{t-1} \times$ crisis & 0.032 & 0.052 & 0.009 & & & \\
\hline$S G_{t-2} \times$ crisis & -0.025 & -0.025 & -0.004 & & & \\
\hline$E G_{t-1}$ & & & & $-0.031^{\star}$ & $-0.045^{\star *}$ & $-0.034^{\star \star}$ \\
\hline$E G_{t-2}$ & & & & 0.009 & 0.017 & -0.006 \\
\hline$E G_{t-1} \times$ crisis & & & & 0.044 & 0.034 & 0.011 \\
\hline$E G_{t-2} \times$ crisis & & & & -0.004 & -0.011 & -0.011 \\
\hline$R O A_{t-1}$ & $-0.131^{\star *}$ & $-0.152^{\star *}$ & $0.125^{\star}$ & $0.029^{\star * *}$ & $0.085^{\star * *}$ & $0.133^{* *}$ \\
\hline$R O A_{t-1} \times$ crisis & 0.029 & $0.049^{\star}$ & $-0.144^{\star * \star}$ & 0.045 & 0.009 & -0.109 \\
\hline Size $_{t-1}$ & $0.053^{* * *}$ & $0.006^{* * *}$ & -0.129 & $0.003^{* * *}$ & $0.003^{* * *}$ & -0.025 \\
\hline Liquidity $_{t-1}$ & $-0.003^{\star * *}$ & $-0.004^{\star *}$ & 0.011 & $-0.003^{\star}$ & $-0.002^{\star}$ & 0.001 \\
\hline Debt $_{t-1}$ & 0.0001 & $0.0183^{\star}$ & -0.216 & -0.012 & -0.012 & 0.084 \\
\hline Intercept & $-0.064^{* * *}$ & $-0.088^{* * *}$ & 0.174 & $-0.044^{* *}$ & $-0.056^{* *}$ & 0.383 \\
\hline Year dummies & Yes & Yes & Yes & Yes & Yes & Yes \\
\hline$n$ & 15,628 & 15,628 & 15,628 & 16,817 & 16,687 & 16,687 \\
\hline$F$ & $82.17^{\star * *}$ & & & $18.46^{* * *}$ & & \\
\hline $\operatorname{AR}(1)$ & & & $-10.42^{\star * *}$ & & & $-4.54^{\star \star *}$ \\
\hline $\mathrm{AR}(2)$ & & & -0.61 & & & -0.18 \\
\hline Wald chi2 & & $260.67^{\star * *}$ & $92.72^{* * *}$ & & $86.48^{* * *}$ & $22.08^{* *}$ \\
\hline Hansen J test & & & 21.27 & & & 22.16 \\
\hline
\end{tabular}

OLS estimation: robust standard errors in parentheses. GLS estimation: heteroskedastic panels corrected standard errors in parentheses. System GMM estimation implemented using a robust two-stage estimator. Robust standard errors in parentheses. The xtabond2 STATA module was used. Hansen J test of overidentifying restrictions. AR (1) and AR (2): z-statistics for first-order and second-order autocorrelation. ${ }^{*} p$-value $<0.1,{ }^{* *} p$-value $<0.05,{ }^{* *} p$-value $<0.001$.

In turn, the results of the OLS, GLS and system GMM regression estimations evidence a positive influence of profitability on employee growth in the short term which is maintained over the crisis period. The coefficient for ROA is $0.133(p<0.001)$ in system GMM and the coefficient of the multiplicative term (ROA $x$ crisis) is not significantly different from zero. 
Table 5 shows the results of the estimation of models in which growth is the factor determining profitability. The first result worth highlighting is that profitability rates seem to persist in the short term and, therefore, a positive association is observed with profitability rates in two previous periods. The coefficients estimated for the first and second ROA lags are positive and statistically significant in all estimated models. In the period of economic crisis, the sign of the coefficient of $R O A_{t-1}$ is negative and significantly different from zero. This result suggests that the persistence of profit, although statistically significant, is lower in crisis $(0.378=0.484$ (ROA coefficient $)-0.106$ (ROA $x$ crisis coefficient $), p$-value $<0.001)$.

Table 5. Results of the panel estimation: profitability model

\begin{tabular}{|c|c|c|c|c|c|c|}
\hline & \multicolumn{3}{|c|}{ ROA (EQ 2) } & \multicolumn{3}{|c|}{ ROA (EQ 2) } \\
\hline & OLS & $G L S$ & $G M M$ & OLS & $G L S$ & $G M M$ \\
\hline$R O A_{t-1}$ & $0.445^{\star * *}$ & $0.386^{* * *}$ & $0.484^{\star * *}$ & $0.432^{\star * *}$ & $0.339^{* * *}$ & $0.496^{* * *}$ \\
\hline$R O A_{t-2}$ & $0.157^{\star * \star}$ & $0.185^{\star * *}$ & $0.171^{\star * *}$ & $0.152^{\star * *}$ & $0.195^{\star * *}$ & $0.182^{\star * *}$ \\
\hline$R O A_{t-1} \times$ crisis & $-0.070^{\star * *}$ & $-0.058^{\star * \star}$ & $-0.106^{\star *}$ & $-0.053^{*}$ & -0.039 & -0.037 \\
\hline$R O A_{t-2} \times$ crisis & 0.106 & -0.001 & -0.028 & 0.005 & -0.011 & -0.002 \\
\hline$S G_{t}$ & $0.113^{\star * *}$ & $0.111^{\star * *}$ & $0.083^{* * *}$ & & & \\
\hline$S G_{t-1}$ & $0.032^{* * *}$ & $0.037^{\star * *}$ & 0.011 & & & \\
\hline$S G_{t} \times$ crisis & $0.022^{\star * *}$ & $0.022^{* * *}$ & 0.012 & & & \\
\hline$S G_{t-1} \times$ crisis & $0.021^{\star * *}$ & $0.021^{\star * *}$ & $0.016^{* *}$ & & & \\
\hline$E G_{t}$ & & & & $0.042^{\star * *}$ & $0.041^{\star * *}$ & 0.001 \\
\hline$E G_{t-1}$ & & & & $0.022^{\star * *}$ & $0.024^{* * *}$ & 0.003 \\
\hline$E G_{t} \times$ crisis & & & & $0.028^{\star *}$ & $0.028^{\star *}$ & 0.025 \\
\hline$E G_{t-1} \times$ crisis & & & & $0.033^{\star * *}$ & $0.034^{\star * *}$ & 0.023 \\
\hline Size $_{t-1}$ & 0.001 & 0.001 & -0.001 & $0.001^{\star \star \star}$ & $0.001^{\star \star \star}$ & -0.014 \\
\hline Liquidity $_{t-1}$ & $-0.002^{\star \star *}$ & $-0.002^{\star * *}$ & -0.002 & $-0.003^{\star \star *}$ & $-0.003^{\star * \star}$ & 0.006 \\
\hline Debt $_{t-1}$ & $-0.012^{\star * *}$ & $-0.012^{\star * *}$ & 0.009 & $-0.011^{\star *}$ & $-0.011^{\star *}$ & 0.018 \\
\hline Intercept & $0.027^{\star * *}$ & $0.027^{\star * *}$ & 0.010 & $0.019^{\star *}$ & $-0.020^{* *}$ & 0.198 \\
\hline Year dummies & Yes & Yes & Yes & Yes & Yes & Yes \\
\hline$n$ & 16,524 & 16,524 & 16,524 & 13,531 & 13,531 & 13,531 \\
\hline$F$ & $251.99^{\star \star \star}$ & & & $155.7^{\star \star *}$ & & \\
\hline $\mathrm{AR}(1)$ & & & $-20.55^{\star * \star}$ & & & $-13.49^{\star * *}$ \\
\hline $\mathrm{AR}(2)$ & & & 0.40 & & & 0.48 \\
\hline Wald chi2 & & $3627.8^{\star * *}$ & $907.04^{\star * *}$ & & $1848.7^{\star * *}$ & $451.30^{\star * *}$ \\
\hline Hansen J test & & & 14.29 & & & 17.15 \\
\hline
\end{tabular}

OLS estimation: robust standard errors in parentheses. GLS estimation: heteroskedastic panels corrected standard errors in parentheses. System GMM estimation implemented using a robust two-stage estimator. Robust standard errors in parentheses. The xtabond2 STATA module was used. Hansen J test of overidentifying restrictions. AR (1) and AR (2): z-statistics for first-order and second-order autocorrelation. ${ }^{\star} p$-value $<0.1,{ }^{* *} p$-value $<0.05,{ }^{* *} p$-value $<0.001$. 
As regards the sales growth and profitability relationship, the coefficients estimated for SG variables are found to be positive and statistically significant. The contemporaneous growth is positively associated with profitability (value of coefficient of $0.083, p$-value $<0.001$ in the system GMM) and this association is similar in the pre-crisis period and during the crisis period. Growth lagged one period was observed significant in OLS and GLS estimates and the relationship is stronger in the crisis period. In the system GMM estimation, the first lag SG coefficient is positive and statistically significant only in the years of economic crisis $(0.016, p$-value $<0.005)$. Consequently, an increase in sales in year $(t)$ is associated to current profits and this greater profitability seems sustainable longer in adverse market conditions.

In contrast, the increase of the number of employees in $t$ and $t-1$ leads to profits in the OLS and GLS estimation but not after controlling for endogeneity. The estimated coefficients for these variables are not statistically significant in the system GMM estimate, neither in the pre-crisis period nor during the crisis.

Finally, regarding the control variables, the estimated models presented in Table 4 seem to indicate a positive relationship between size and growth and a negative and significant relationship with growth and liquidity in OLS and GLS estimates but not in system GMM. The values in Table 5 show a significant relationship between the three control variables and profitability, but only in OLS and GLS estimates.

\subsection{The effect of a firm's strategies on the growth-profit relationship}

We analyzed the influence of firms' internationalization and innovation strategies in the dynamic relationship between growth and profitability. Figure 1 shows the development over time of the number of firms in the sample that either follows one or both of these strategies or neither of them. Firstly, it can be seen that the average percentage of firms implementing one of these strategies is approximately $70 \%$. Of these, exporting is the strategy chosen by the highest number of Spanish manufacturing companies during the fifteen years analyzed. As of 2008, this strategy becomes more relevant, with a rising trend throughout the period. When a firm has opted for innovation, it is also usually committed to exports. The percentage of firms implementing both strategies is $31 \%$ on average, while the percentage of firms that only innovate drops to $4 \%$.

To sum up, although many firms decided to opt for innovation and/or exports, $30 \%$ of the sample had still not implemented any of the proposed strategies. Analyzing the influence of the strategies on this period's growth and profitability is, therefore, of interest.

The direct influence of innovation and export intensity on growth and profitability is tested by including Export and Innov as exogenous variables in equations (3) and (4). To check the presence of moderating effects of strategies on the growth-profit relationship, we estimate the interaction terms of innovation and profit ( $R O A x$ Innov), exportation and profit (ROA $x$ Export) on firm growth and interaction effects of innovation and growth (GR $x$ Innov), exportation and growth (GR $x$ Export) on profitability. To analyze the influence of economic crisis in the results, given the difficulty of interpreting interaction term of three variables, the models have been estimated splitting the sample into two periods, pre-crisis and crisis period. 


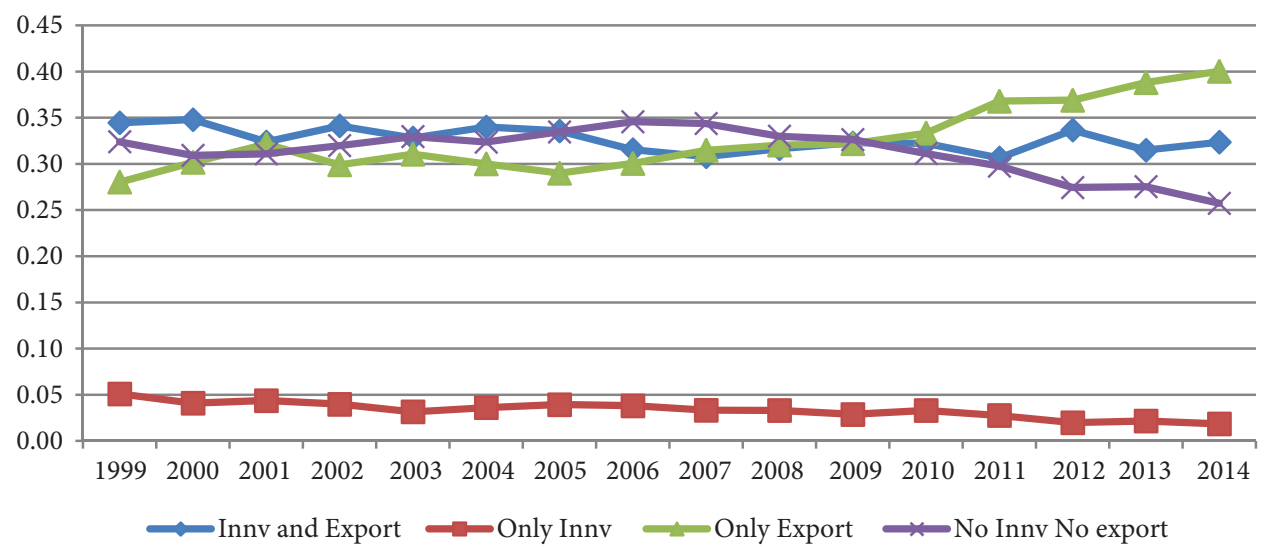

Figure 1. Companies that implemented innovation and/or export strategies in the 2000-2014 period (\%)

The results of the system GMM estimation are shown in Table 6. We observed that the effect of the export intensity is positive and statistically significant for sales and for employee growth rates throughout the period analyzed. Innovation strategy does not show relationship to employee growth and only the estimated coefficient for Innov in the pre-crisis period is positive and statistically significant in the sales growth model $(0.718, p$-value $<0.001)$.

Concerning the moderation analysis, the coefficient of the multiplication term ROA $\mathrm{x}$ Export is -0.146 (p-value $<0.1$ ) during the years of economic crisis in the model in which the dependent variable is the growth of sales (EQ 3). The negative value would imply that the higher the profitability the lower (less positive) the effect of export activity on sales growth. The rest of the interaction terms are not statistically significant.

Table 6. System GMM regression results: strategies on profitability-growth relationship

\begin{tabular}{|l|c|c|c|c|c|c|c|c|}
\hline \multirow{2}{*}{$\begin{array}{c}\text { Dependent } \\
\text { variable: }\end{array}$} & \multicolumn{2}{|c|}{$S G(\mathrm{EQ} 3)$} & \multicolumn{2}{c|}{$E G(\mathrm{EQ} 3)$} & \multicolumn{2}{c|}{$R O A(\mathrm{EQ} 4)$} & \multicolumn{2}{c|}{$R O A(\mathrm{EQ} 4)$} \\
\cline { 2 - 9 } & $2000-$ & $2008-$ & $2000-$ & $2008-$ & $2000-$ & $2008-$ & $2000-$ & $2008-$ \\
2007 & 2007 & 2014 & 2007 & 2014 & 2007 & 2014 \\
\hline$S G_{t}$ & & & & & $0.161^{* * *}$ & $0.093^{* * *}$ & & \\
\hline$S G_{t-1}$ & $-0.041^{* * *}$ & $-0.048^{* * *}$ & & & 0.023 & $0.031^{* * *}$ & & \\
\hline$S G_{t-2}$ & -0.021 & $-0.199^{* * *}$ & & & & & & \\
\hline$E G_{t}$ & & & & & & & 0.025 & 0.033 \\
\hline$E G_{t-1}$ & & & 0.012 & $-0.048^{* * *}$ & & & 0.039 & $0.035^{*}$ \\
\hline$E G_{t-2}$ & & & 0.006 & $-0.075^{* * *}$ & & & & \\
\hline$R O A_{t-1}$ & 0.001 & 0.028 & $0.143^{* *}$ & $0.119^{* *}$ & $0.622^{* * *}$ & $0.387^{* * *}$ & $0.241^{* * *}$ & $0.401^{* * *}$ \\
\hline$R O A_{t-2}$ & & & & & $0.038^{*}$ & $0.148^{* * *}$ & $0.090^{* * *}$ & $0.207^{* * *}$ \\
\hline Innov $_{t-1}$ & $0.718^{* * *}$ & 0.435 & 0.012 & 0.099 & $-0.321^{* *}$ & $0.157^{*}$ & 0.138 & 0.101 \\
\hline Export $_{t}$ & $0.082^{* * *}$ & $0.218^{* * *}$ & $0.029^{*}$ & $0.022^{*}$ & 0.005 & 0.006 & -0.004 & $0.014^{* *}$ \\
\hline
\end{tabular}


End of Table 6

\begin{tabular}{|c|c|c|c|c|c|c|c|c|}
\hline \multirow{2}{*}{$\begin{array}{l}\text { Dependent } \\
\text { variable: }\end{array}$} & \multicolumn{2}{|c|}{$S G($ EQ 3) } & \multicolumn{2}{|c|}{$E G$ (EQ 3) } & \multicolumn{2}{|c|}{ ROA (EQ 4) } & \multicolumn{2}{|c|}{ ROA (EQ 4) } \\
\hline & $\begin{array}{l}2000- \\
2007\end{array}$ & $\begin{array}{c}2008- \\
2014\end{array}$ & $\begin{array}{l}2000- \\
2007\end{array}$ & $\begin{array}{c}2008- \\
2014\end{array}$ & $\begin{array}{l}2000- \\
2007\end{array}$ & $\begin{array}{c}2008- \\
2014\end{array}$ & $\begin{array}{c}2000- \\
2007\end{array}$ & $\begin{array}{c}2008- \\
2014\end{array}$ \\
\hline $\begin{array}{l}R O A \times \text { In- } \\
\text { nov }\end{array}$ & -1.989 & -1.92 & -0.131 & -0.099 & & & & \\
\hline $\begin{array}{l}R O A \times \\
\text { Export }\end{array}$ & -0.208 & $-0.146^{\star}$ & -0.189 & -0.085 & & & & \\
\hline$S G \times$ Innov & & & & & -0.016 & -0.149 & & \\
\hline $\begin{array}{l}S G \times \mathrm{Ex}^{-} \\
\text {port }\end{array}$ & & & & & $0.108^{*}$ & $0.053^{* * *}$ & & \\
\hline$E G \times$ Innov & & & & & & & 0.153 & 1.078 \\
\hline $\begin{array}{l}E G \times E^{-}- \\
\text {port }\end{array}$ & & & & & & & 0.037 & $0.134^{* * *}$ \\
\hline Size $_{\text {t-1 }}$ & $0.003^{*}$ & $0.007^{* * *}$ & $0.002^{*}$ & $0.003^{* *}$ & 0.005 & 0.005 & $-0.001^{\star}$ & $0.002^{*}$ \\
\hline Liquidity $_{t-1}$ & -0.001 & -0.013 & -0.003 & $-0.005^{\star}$ & -0.002 & -0.001 & $-0.002^{\star}$ & -0.004 \\
\hline $\operatorname{Debt}_{t-1}$ & -0.006 & -0.007 & -0.002 & $-0.034^{\star *}$ & -0.004 & $0.036^{\star *}$ & -0.015 & $0.048^{*}$ \\
\hline Intercept & $-0.081^{\star *}$ & $-0.234^{\star *}$ & -0.015 & $-0.096^{\star *}$ & 0.025 & 0.236 & $0.032^{* *}$ & 0.002 \\
\hline Year & Yes & Yes & Yes & Yes & Yes & Yes & Yes & Yes \\
\hline$n$ & 6,247 & 4,990 & 4,831 & 4,791 & 6,374 & 6,715 & 5,430 & 5,415 \\
\hline$A R(1)$ & $-16.51^{\star * *}$ & $-11.71^{* * *}$ & $-8.57^{\star * *}$ & $-12.01^{* * *}$ & $-4.93^{\star * *}$ & $-13.5^{\star \star \star}$ & $-8.15^{\star * *}$ & $-10.17^{\star * *}$ \\
\hline$A R(2)$ & -0.97 & -1.78 & 1.70 & 0.94 & 1.23 & -1.38 & -0.88 & -1.61 \\
\hline Wald chi2 & $68.73^{\star * *}$ & $209.25^{\star * *}$ & $42.3^{* * *}$ & $64.71^{\star * *}$ & $365.95^{\star * *}$ & $365.84^{* * *}$ & $133.3^{* * *}$ & $212.79^{\star * *}$ \\
\hline $\begin{array}{l}\text { Hansen J } \\
\text { test }\end{array}$ & 15.89 & 14.03 & 12.07 & 9.63 & 12.73 & 14.13 & 7.9 & 7.91 \\
\hline
\end{tabular}

System GMM estimation implemented using a robust two-stage estimator. Robust standard errors in parentheses. The xtabond2 STATA module was used. Hansen J test of overidentifying restrictions. AR (1) and AR (2): z-statistics for first-order and second-order autocorrelation. ${ }^{*} p$-value $<0.1,{ }^{* *} p$-value $<0.05,{ }^{* * *} p$-value $<0.001$.

In profitability models, the results are not conclusive. The association between exports and ROA is positive and statistically significant in the crisis period and in the EG model $(0.014, p$-value $<0.05)$. In contrast, the estimated coefficient for Innov is statistically significant in the SG model, negative in pre-crisis period and positive in the years of crisis. Given that the estimated models show that growth in the period $(t)$ does have a positive impact on profitability and, in turn, these growth rates are explained by the firm's exporting orientation, the results of the estimation of model (EQ 4) may be a consequence of moderating relationships. Consequently, an export strategy may create profitability but only if it is accompanied by a growth in sales, or employee's growth, in the crisis period. The effect of exporting on profitability would be indirect through growth.

The results of profitability model (EQ 4), evidence that export intensity and sales growth interact to produce a positive effect on current profitability (coefficient estimated of SG $\times$ Export $=0.108, p$-value $<0.1$, in pre-crisis period and $0.053, p$-value $<0.001$, in the period 
of crisis). In the model in which EG is the growth measure, the product term between EG and Export is positive and statistically significant in the crisis period $(0.134, p$-value $<0.001)$, telling us that the increase in employees leads profitability when it is associated with greater export intensity.

\section{Discussion}

The empirical analysis shows first, that sales growth affects profit positively and this relationship is robust across the different estimation methods applied and the different economic periods. Moreover, the association between sales growth and $R O A$ is greater in the crisis period. For the relationship between employee's growth and profitability, however, the results of the estimates are not completely conclusive.

The positive effect of an increase in sales on profitability is in keeping with the results evidenced in prior studies. The effect is also produced immediately, in other words, current growth affects profits positively. As Penrose (1959) states "economies of growth" are a temporary phenomenon and disappear as the company grows. In contrast, in the years of economic crisis, we also evidence a positive effect of one year lagged sales growth on profits, that is a more persistent relationship between them.

Secondly, our results show that past profits enhance subsequent employee's growth. However, unlike expected, profitability does not show a consistent effect on sales growth. Once we account for endogeneity, past profitability shows a slight positive relationship with sales growth in pre-crisis period, but it is not significant in the crisis period. Thus, while past profitability has not been a determining factor to increase sales, companies that increased their workforce during the analyzed period required profits in the previous year. In the same way, the more negative the profitability, the greater the job destruction.

Early empirical evidence of no effect or a negative effect of profitability on growth is scarce. We consider our result is a consequence of the recession period the study concerns. Studies by Lee (2014), Yoo and Kim (2015), focused on analyzing the Korean market, conducted in a similar period, are consistent with our findings. The explanation they provide is that firms may refuse to increase their capacity through additional investments and tend to take a short-term view to maintain profitability as a result of the recession context affecting the country. In this line Delmar, McKelvie, and Wennberg (2013), Federico and Capelleras (2015), in their samples of young firms, also evidence that past profits do not have a significant impact on firm growth rates, which may indicate that many firms choose not to seek growth due to the potential threats to survival.

Making a profit does not alone necessarily ensure growth. Where the profit is spent will depend on the commitments the firm has established previously, such as financial obligations. Typical obligations include issuing dividends to shareholders, paying creditors and lowering debt levels. Additionally, irrespective of already committed profits, companies may not see expansionary efforts as a prudent way to allocate money. It can also be interpreted as a defensive posture adopted by companies so that more profits could arise from a firm's strategic decisions in response to economy-wide shocks. In a downturn period, firms could adopt conservative policies and save their profits as a means to protect the organization from a drop 
in consumer spending. The two ways of increasing profit margins are increasing product sale prices or cutting costs. Given that increasing prices does not seem appropriate in periods of low demand, cutting costs to improve efficiency and maintain competitive advantages seems to be the solution to generate profits. Logically, cutback policies are not compatible with processes of expansion that require significant additional expenditure. We could say, therefore, that Spanish manufacturing companies have focused on short-term profitability and tend to avoid investing in growth.

Regarding the persistence of growth and profitability rates, the inclusion of 1-year and 2-year lagged values of growth and profitability in the models has led us to reject the hypothesis that profitability and growth follow a random-walk process, both in favorable economic periods and in recession periods. A reversion pattern of growth was observed in the short term, while profitability showed a positive autocorrelation in two consecutive periods. Consequently, growth was proven to be temporary and volatile, while profitability was maintained in a short period of time, two years. In the crisis period, our results evidence that the effect of one-year lagged profitability on current profits was weaker (lower coefficients) although the relationship remained statistically significant. We consider that the results are in keeping with the economic recession context.

The introduction of strategies in the growth-profit relationship has highlighted that export was the strategy that enabled Spanish manufacturing firms to grow throughout the period analyzed. However, the effect of the strategies on profitability was not so evident. We found that the export strategy moderates the impact of growth on profits, being this effect stronger in the crisis period. We did not find support for the mediator role of the innovation between firm growth and profitability.

\section{Conclusions}

The study results show that in an economic crisis period sales growth leads to profits but previous profits are not required to achieve growth in sales. The adverse economic context does not necessarily prevent business growth, as this depends on how the firm addresses these hostile conditions. Specifically, this depends on whether the firms decide to adopt appropriate strategies that enable them to overcome the conditions of a volatile market.

This results are interesting for both managers, to learn from other firms that survived the crisis, and for policy makers while designing policy to firms during recession (for instance, with respect to access to finance).

The limitations of this paper come from the study of a specific context. A useful extension of this work would be first to consider whether the impact of country (financial stability, country risk, and crisis location) and firm-specific characteristics could change the evidenced relationship between growth and profit. Comparative analysis of contextual factors would help investigate this issue. Second, when larger data set becomes available, an important application would be to assess in the medium term whether the firms that have managed to ride the crisis better are those that opted for a conservative (profit-oriented) policy or those that opted for growth. This would allow us to establish a roadmap for growth and profitability in adverse market conditions. A third useful extension would be to test the strategies firms 
adopt in a recession period to address profitability and growth, and to extend the analysis to other measures of innovation and internationalization strategies or even other growth strategies.

\section{Acknowledgements}

The authors are grateful to anonymous referees for their comments, which contributed greatly to this final version.

\section{Funding}

The work reported in this article was supported by the European Regional Development Fund and by the Government of Aragon [grant S38_17R].

\section{Author contributions}

Both authors contributed equally in the design and development of the paper.

\section{Disclosure statement}

The authors have no competing financial, professional, or personal interests from other parties that are related to the subject of this paper.

\section{References}

Alarcón, S., \& Sánchez, M. (2016). Is there a virtuous circle relationship between innovation activities and exports? A comparison of food and agricultural firms. Food Policy, 61(May), 70-79. https://doi.org/10.1016/j.foodpol.2016.02.004

Alchian, A. (1950). Uncertainty, evolution, and economic theory. Journal of Political Economy, 58(3), 211-221. https://doi.org/10.1086/256940

Amidu, M., \& Harvey, S. (2016). The persistence of profits of banks in Africa. Review of Quantitative Finance and Accounting, 47, 83-108. https://doi.org/10.1080/00036846.2018.1489111

Arellano, M., \& Bond, S. (1991). Some tests of specification for panel data: Monte Carlo evidence and an application to employment equations. Review of Economic Studies, 58, 277-297. https://doi.org/10.2307/2297968

Arellano, M., \& Bover, O. (1995). Another look at the instrumental variable estimation of error-components models. Journal of Econometrics, 68(1), 29-51. https://doi.org/10.1016/0304-4076(94)01642-D

Blundell, R., \& Bond, S. (1998). Initial conditions and moment restrictions in dynamic panel data models. Journal of Econometrics, 87(1), 115-143. https://doi.org/10.1016/S0304-4076(98)00009-8

Boermans, M., \& Roelfsema, H. (2016). Small firm internationalization, innovation, and growth. International Economics and Economic Policy, 13(2), 283-296. https://doi.org/10.1007/s10368-014-0310-y

Bottazzi, G., Dosi, G., Lippi, M., Pammolli, F., \& Riccaboni, M. (2001). Innovation and corporate growth in the evolution of the drug industry. International Journal of Industrial Organization, 19(7), 1161-1187. 
Bottazzi, G., Coad, A., Jacoby, N., \& Secchi, A. (2011). Corporate growth and industrial dynamics: Evidence from French manufacturing. Applied Economics, 43(1), 103-116. https://doi.org/10.1080/00036840802400454

Burger, A., Damijan, J., Kostevc, C., \& Rojec, M. (2017). Determinants of firm performance and growth during economic recession: The case of Central and Eastern European countries. Economic Systems, 41(4), 569-590. https://doi.org/10.1016/j.ecosys.2017.05.003

Cable, J. R., \& Mueller, D. C. (2008). Testing for persistence of profits' differences across firms. International Journal of the Economics of Business, 15(2), 201-228. https://doi.org/10.1080/13571510802134353

Canarella, G., \& Miller, S. (2018). The determinants of growth in the Information and Communication Technology (ICT) industry: A firm-level analysis. Economic Modelling, 70(C), 259-271. https://doi.org/10.1016/j.econmod.2017.11.011

Caves, R. E. (1996). Multinational enterprise and economic analysis (Second edition). Cambridge: Cambridge University Press. https://doi.org/10.1017/CBO9780511619113

Chao, M. C. H., \& Kumar, V. (2010). The impact of institutional distance on the international diversity-performance relationship. Journal of World Business, 45(1), 93-103.

https://doi.org/10.1016/j.jwb.2009.04.005

Cho, H. J., \& Pucik, V. (2005). Relationship between innovativeness, quality, growth, profitability, and market value. Strategic Management Journal, 26(6), 555-575. https://doi.org/10.1002/smj.461

Coad, A. (2007). Testing the principle of 'growth of the fitter': the relationship between profits and firm growth. Structural Change and Economic Dynamics, 18(3), 370-386. https://doi.org/10.1016/j.strueco.2007.05.001

Coad, A., \& Rao, R. (2008). Innovation and firm growth in high-tech sectors: A quantile regression approach. Research Policy, 37(4), 633-648. https://doi.org/10.1016/j.respol.2008.01.003

Coad, A., Frankish, J., Roberts, R., \& Storey, D. (2013). Growth paths and survival chances: An application of Gambler's Ruin theory. Journal of Business Venturing, 28(5), 615-632. https://doi.org/10.1016/j.jbusvent.2012.06.002

Coad, A., Daunfeldt, S., \& Halvarsson, D. (2018). Bursting into life: firm growth and growth persistence by age, Small Business Economics, 50(1), 55-75. https://doi.org/10.1007/s11187-017-9872-8

Cowling, M. (2004). The growth-profit nexus. Small Business Economics, 22(1), 1-9. https://doi.org/10.1023/B:SBEJ.0000011568.42714.c9

Daunfeldt, S., \& Halvarsson, D. (2015). Are high-growth firms one-hit wonders? Evidence from Sweden. Small Business Economics, 44(2), 361-383. https://doi.org/10.1007/s11187-014-9599-8

Davidsson, P., Steffens, P., \& Fitzsimmons, J. (2009). Growing profitable or growing from profits: Putting the horse in front of the cart?. Journal of Business Venturing, 24(4), 388-406. https://doi.org/10.1016/j.jbusvent.2008.04.003

Delmar, F., McKelvie, A., \& Wennberg, K. (2013). Untangling the relationships among growth, profitability and survival in new firms. Technovation, 33(8-9), 276-291. https://doi.org/10.1016/j.technovation.2013.02.003

Demirel, P., \& Mazzucato, M. (2012). Innovation and firm growth: Is R\&D worth it?. Industry and Innovation, 19(1), 45-62. https://doi.org/10.1080/13662716.2012.649057

European Commission. (2014). For a European Industrial Renaissance. COM (2014)14. Retrieved from http://eur-lex.europa.eu/legal-content/EN/ALL/?uri=CELEX:52014DC0014

Federico, J. S., \& Capelleras, J. L. (2015). The heterogeneous dynamics between growth and profits: the case of young firms. Small Business Economics, 44(2), 231-253.

https://doi.org/10.1007/s11187-014-9598-9

Ferrando, F., Marchica, M. T., \& Mura, M. (2017). Financial flexibility and investment ability across the Euro area and the UK. European Financial Management, 23(1), 87-126.

https://doi.org/10.1111/eufm.12091 
Filatotchev, I., \& Piesse, J. (2009). R\&D, internationalization and growth of newly listed firms: European evidence. Journal of International Business Studies, 40(8), 1260-1276.

https://doi.org/10.1057/jibs.2009.18

Fitzsimmons, J., Steffens, P., \& Douglas, E. (2005). Growth and profitability in small and medium sized Australian firms. In Proceedings AGSE Entrepreneurship Exchange. Melbourne.

https://doi.org/10.2139/ssrn.1263734

Geringer, J., Tallman, S., \& Olsen, D. (2000). Product and international diversification among Japanese multinational firms. Strategic Management Journal, 21, 51-80. https://doi.org/10.1002/(SICI)1097-0266(200001)21:1<51::AID-SMJ77>3.0.CO;2-K

Geroski, P., \& Machin, S. (2013). Think again: do innovating firms outperform non-innovators?. Business Strategy Review, 24(2), 82-86. https://doi.org/10.1111/j.1467-8616.2013.00959.x

Gibrat, R. (1931). Les Inégalités Économiques. Paris: Recueil Sirey.

Giotopoulos, I., \& Fotopoulos, G. (2010). Intra-industry growth dynamics in the Greek services sector: firm-level estimates for ICT-producing, ICT-using, and non-ICT industries. Review of Industrial Organization, 36(1), 59-74. https://doi.org/10.1007/s11151-010-9241-0

Goddard, J. A., Molyneux, P., \& Wilson, J. (2004). Dynamics of growth and profitability in banking. Journal of Money, Credit, and Banking, 36(6), 1069-1090. https://doi.org/10.1353/mcb.2005.0015

Goddard, J. A., Liu, H., Molyneux, J., \& Wilson, J. (2013). Article: Do bank profits converge? European Financial Management, 19(2), 345-365. https://doi.org/10.1111/j.1468-036X.2010.00578.x

Golovko, E., \& Valentini, G. (2011). Exploring the complementarity between innovation and export for SMEs' growth. Journal of International Business Studies, 42(3), 362-380. https://doi.org/10.1057/jibs.2011.2

Gugler, K., \& Peev, E. (2018). The persistence of profits in banking: An international comparison. Applied Economics, 50(55), 5996-6009. https://doi.org/10.1080/00036846.2018.1489111

Gupta, V. K. (1981). Minimum efficient scale as a determinant of concentration: A reappraisal. The Manchester School, 49(2), 153-164. https://doi.org/10.1111/j.1467-9957.1981.tb00943.x

Guarascio, D., \& Pianta, M. (2017). The gains from technology: new products, exports and profits. Economics of Innovation and New Technology, 26(8), 779-804. https://doi.org/10.1080/10438599.2016.1257446

Hakala, H. (2011). Strategic orientations in management literature: Three approaches to understanding the interaction between market, technology, entrepreneurial and learning orientations. International Journal of Management Reviews, 13(2), 199-217. https://doi.org/10.1111/j.1468-2370.2010.00292.x

Hirsch, S. (2018). Successful in the long run: A meta-regression analysis of persistent firm profit. Journal of Economic Surveys, 32(1), 23-49. https://doi.org/10.1111/joes.12188

Hsu, W. T., Chen, H. L., \& Cheng, C. Y. (2013). Internationalization and firm performance of SMEs: The moderating effects of CEO attributes. Journal of World Business, 48(1), 1-12. https://doi.org/10.1016/j.jwb.2012.06.001

Jang, S., \& Park, K. (2011). Inter-relationship between firm growth and profitability. International Journal of Hospitality Management, 30(4), 1027-1035. https://doi.org/10.1016/j.ijhm.2011.03.009

Kachlami, H., \& Yazdanfar, D. (2016). Determinants of SME growth: The influence of financing pattern. An empirical study based on Swedish data, Management Research Review, 39(9), 966-986. https://doi.org/10.1108/MRR-04-2015-0093

Kirzner, I. M. (1979). Perception, opportunity and profit. Chicago: University of Chicago Press.

Lee, S. H., Beamish, P., Lee, H. U., \& Park, J. H. (2009). Strategic choice during economic crisis: Domestic market position, organizational capabilities and export flexibility. Journal of World Business, 44(1), 1-15. https://doi.org/10.1016/j.jwb.2008.03.015

Lee, S. (2014). The relationship between growth and profit: evidence from firm-level panel data. Structural Change and Economic Dynamics, 28(March), 1-11. https://doi.org/10.1016/j.strueco.2013.08.002 
Lee, S. (2018). Growth, profits and R\&D investment. Economic Research, 31, 607-625. https://doi.org/10.1080/1331677X.2018.1432380

Lööf, H., \& Heshmati, A. (2006). On the relationship between innovation and performance: A sensitivity analysis. Economics of Innovation and New Technology, 15(4-5), 317-344. https://doi.org/10.1080/10438590500512810

Markman, G. D., \& Gartner, W. B. (2002). Is extraordinary growth profitable? A study of Inc. 500 highgrowth companies. Entrepreneurship Theory and Practice, 27(1), 65-75. https://doi.org/10.1111/1540-8520.t01-2-00004

Moscarini, G., \& Postel-Vinay, F. (2012). The Contribution of large and small employers to job creation in times of high and low unemployment. American Economic Review, 102(6), 2509-2539. https://doi.org/10.1257/aer.102.6.2509

Mueller, D. C. (Ed.) (1990). Dynamics of Company Profits: An International Comparison. Cambridge: Cambridge University Press.

Nickell, S. (1981). Biases in dynamic models with fixed effects. Econometrica, 49(6), 1417-1426. https://doi.org/10.2307/1911408

Pangarkar, N. (2008). Internationalization and performance of small- and medium-sized enterprises. Journal of World Business, 43, 475-485. https://doi.org/10.1016/j.jwb.2007.11.009

Pattitoni, P., Petracci, B., \& Spisni, M. (2014). Determinants of profitability in the EU-15 area. Applied Financial Economics, 24(11), 763-775. https://doi.org/10.1080/09603107.2014.904488

Penrose, E. T. (1959). The theory of the growth of the firm. New York. NY: John Wiley.

Reichstein, T., Dahl, M. S., Ebersberger, B., \& Jensen, M. B. (2010). The devil dwells in the tails. Journal of Evolutionary Economics, 20(2), 219-231. https://doi.org/10.1007/s00191-009-0152-x

Riahi-Belkaoui, A. (1998). The effects of the degree of internationalization on firm performance. International Business Review, 7(3), 315-321. https://doi.org/10.1016/S0969-5931(98)00013-4

Rodil, O., Vence, X., \& Sánchez, M. C. (2016). The relationship between innovation and export behaviour: The case of Galician firms. Technological Forecasting \& Social Change, 113, (part B), 248-265. https://doi.org/10.1016/j.techfore.2015.09.002

Roodman, D. (2006). How to do xtabond2: An introduction to difference and system GMM in Stata. The Stata Journal, 9(1), 86-136.

Rousseau, M., Blake, D., Madden, L., \& Crook, T. (2016). Innovation, firm performance, and appropriation: A meta-analysis. International Journal of Innovation Management, 20(3), 1-29. https://doi.org/10.1142/S136391961650033X

Shaver, J. (2011). The benefits of geographic sales diversification: How exporting facilitates capital investment. Strategic Management Journal, 32, 1046-1060. https://doi.org/10.1002/smj.924

Schumpeter, J. A. (1934). The theory of economic development: An inquiry into profits, capital, credit, interest, and the business cycle. Reprint, Cambridge, MA: Harvard University Press.

Tsoulfidis, L., Alexiou, C., \& Parthenidis, T. (2015). Revisiting profit persistence and the stock market in Japan. Structural Change and Economic Dynamics, 33, 10-24.

https://doi.org/10.1016/j.strueco.2015.02.001

Yoo, S., \& Kim, J. (2015). The dynamic relationship between growth and profitability under long-term recession: The case of Korean construction companies. Sustainability, 7(12), 15982-15998. https://doi.org/10.3390/su71215796

Zaheer, S. (1995). Overcoming the liability of foreignness. Academy of Management Journal, 38(2), 341-363. https://doi.org/10.2307/256683 